\title{
Trends in Renewable Energy: An Overview 2020
}

\author{
Monali Patil ${ }^{1}$, Anushka Patil ${ }^{2}$, Nikhita Chougale ${ }^{3}$, Ashlesha Patil ${ }^{4}$ \\ 1,2,3,4 Student, Department of Electrical Engineering, \\ KIT's college of engineering Kolhapur
}

\begin{abstract}
India is now one of the countries with large production of energy from renewable sources. The renewable energy system represents a unique opportunity for creating new employment with climate goals and increasing economic growth, and enhancing human welfare. Hence the role of renewable energy is very important and has been assuming increasing significance in recent times with the growing concern for energy security. This paper represents the current trends of renewable energy particularly in India as well as their growth and issues.
\end{abstract}

Keywords - Renewable energy, economic growth, India

\section{INTRODUCTION}

India was the first country in the world to set up a ministry of renewable energy (Ministry of New and Renewable Energy (MNRE)), in the early 1980s, due to public sector undertakings the Solar Energy Corporation of India development of solar energy industry in India, is possible. Hydroelectricity is administered separately by the Ministry of Power and it is not included in MNRE targets.

India ranks second position in terms of population which is $18 \%$ of world's overall population. As the population increases in India, it makes India to rank fourth place in consumption of energy in the globe. As fossil fuels are decreasing and creating more pollution due to which global warming causes and also energy demand is increasing day by day, energy production from renewable energy resources becomes the best solution in the present condition as renewable energy resources are clean, green and not exhaustible energy.

India has a strong manufacturing base in wind power with 20 manufactures of 53 different wind turbine models of international quality which are up to $3 \mathrm{MW}$ in size with exports to Europe, the United States and other countries. Wind or Solar PV paired with four-hour battery storage systems is already cheap in cost as compared to other. And most importantly it is without subsidy and as a source of dispatchable generation as compared to new coal and new gas plants in India.

\section{SCENARIO:}

- In 2019 India was on rank fourth for most attractive renewable energy market in the world. The India has set an ambitious target of $450 \mathrm{GW}$ of renewable energy by 2030.This is the world's largest expansion plan in renewable energy.

Up to 30 April 2020, the total installed capacity for Renewable energy is $87+\mathrm{GW}$ with the following details:

- Wind power: $38 \mathrm{GW}$

- Solar Power: $35 \mathrm{GW}$

- Biopower: $10 \mathrm{GW}$
- Small Hydro Power: 5 GW

In the last 4 years wind energy capacity in India has increased by 1.7 times. Then further it is increased continuously with the record $100 \mathrm{bn}+$ units of renewable electricity generating last year.

- In March 2019 Solar power capacity has increased by more than 11 times in the last five years from $2.6 \mathrm{GW}$ to $28.18 \mathrm{GW}$. In 17 states up to March 201942 solar parks of aggregate capacity 23,499 MW have been approved.

- fully operational Solar Parks are Kurnool (1,000 MW) and Bhadla-II (648 MW) in PavagadaLargest Solar Park of 2,000 MW is under installation.

- According to survey till 31 March 2020,35.86\% of India's installed electricity generation capacity is from renewable sources. It is generating $21.22 \%$ of total utility electricity in the country, from renewable energy sources.

- According to October 2019 survey, $175 \mathrm{GW}$ is the target, $83 \mathrm{GW}$ is already operational, $29 \mathrm{GW}$ is under installation, $30 \mathrm{GW}$ is under bidding, and remaining $43 \mathrm{GW}$ is under planning.175 $\mathrm{GW}$ interim target is $100 \mathrm{GW}$ of solar, $60 \mathrm{GW}$ of wind, $10 \mathrm{GW}$ of bio mass and $5 \mathrm{GW}$ of small hydro.

- According to $2019,35 \%$ total power production get from renewable energy,, $13 \%$ or $45.399 \mathrm{GW}$ of the total from all sources comes from large hydro projects, $10 \%$ or $36,686.82 \mathrm{GW}$ of the total from all sources from wind power which is fourth-largest in the world, $8 \%$ or $9.1 \mathrm{GW}$ of total power from all sources from Biomass power from biomass combustion, biomass_gasification and bagasse cogeneration.

The government set the target of installing $20 \mathrm{GW}$ of solar power by 2022. But it was achieved four years ahead of schedule in January 2018, which are through both solar parks as well as roof-top solar panels. After that India set a new target of achieving $100 \mathrm{GW}$ of solar power, $60 \mathrm{GW}$ of wind power, $10 \mathrm{GW}$ of bio mass and $5 \mathrm{GW}$ of small hydro power by 2022. India has three of the top Five largest solar parks in the world. It also includes the second-largest solar park in the world at Kurnool, Andhra Pradesh, with a capacity of $1000 \mathrm{MW}$. In Rajasthan the world's largest solar power plant, Bhadla Solar Park exist with a capacity of $2255 \mathrm{MW}$.

The government has announced that no any new coalbased capacity addition is required beyond the $50 \mathrm{GW}$ under different stages of construction which are to come online between 2017 and 2022. With the expansion of renewable power generation capacity, due to the weak purchasing capacity. 
the outstanding payment dues from the power purchasers are also increasing rapidly.

\begin{tabular}{|l|l|l|}
\hline Source & $\begin{array}{l}\text { Total Installed } \\
\text { Capacity (MW) }\end{array}$ & $\begin{array}{l}\mathbf{2 0 2 2} \text { target } \\
\text { (MW) }\end{array}$ \\
\hline Wind power & $37,693.75$ & 60,000 \\
\hline Solar power & $34,627.82$ & 100,000 \\
\hline $\begin{array}{l}\text { Biomass power } \\
\text { (Biomass \& Gasification and } \\
\text { Bagasse Cogeneration) }\end{array}$ & $9,875.31$ & $* 10,000$ \\
\cline { 1 - 2 } Waste-to-Power & 147.64 & \\
\cline { 1 - 2 } Small hydropower & $4,683.16$ & 5,000 \\
\hline TOTAL & $\mathbf{8 7 , 0 2 7 . 6 8}$ & $\mathbf{1 7 5 , 0 0 0}$ \\
\hline
\end{tabular}

Grid connected installed capacity from all sources according to 31 March 2020

\begin{tabular}{|l|l|l|}
\hline Source & Installed Capacity (MW) & Share \\
\hline Coal & $205,134.50$ & $55.43 \%$ \\
\hline Large hydro & $45,699.22$ & $12.35 \%$ \\
\hline Other renewables & $87,027.68$ & $23.51 \%$ \\
\hline Gas & $24,955.36$ & $6.74 \%$ \\
\hline Diesel & 509.71 & $0.14 \%$ \\
\hline Nuclear & $6,780.00$ & $1.83 \%$ \\
\hline Total & $\mathbf{3 7 0 , 1 0 6 . 4 6}$ & $\mathbf{1 0 0 . 0 0 \%}$ \\
\hline
\end{tabular}

In India during the year 2017-18 total renewable energy which includes large hydro with pumped storage generation, is nearly $17.5 \%$ of total utility electricity generation. Solar, wind and hydro are the important and trending power generation and it is environment friendly. Base load coal fired power is transforming into following sources of power generation. In addition, renewable energy sources peaking hydro power capacity and also caters peak load demand on daily basis.

\begin{tabular}{|l|l|l|l|l|l|l|}
\hline Source & $\mathbf{2 0 1 4 - 1 5}$ & $\mathbf{2 0 1 5 - 1 6}$ & $\mathbf{2 0 1 6 - 1 7}$ & $\mathbf{2 0 1 7 - 1 8}$ & $\mathbf{2 0 1 8 - 1 9}$ & $\begin{array}{l}\mathbf{2 0 1 9}- \\
\mathbf{2 0 2 0}\end{array}$ \\
\hline $\begin{array}{l}\text { Large } \\
\text { Hydro }\end{array}$ & 129,244 & 121,377 & 122,313 & 126,134 & 135,040 & $\begin{array}{l}155,97 \\
0\end{array}$ \\
\hline $\begin{array}{l}\text { Small } \\
\text { Hydro }\end{array}$ & 8,060 & 8,355 & 7,673 & 5,056 & 8,703 & 9,366 \\
\hline Solar & 4,600 & 7,450 & 12,086 & 25,871 & 39,268 & 50,103 \\
\hline Wind & 28,214 & 28,604 & 46,011 & 52,666 & 62,036 & 64,639 \\
\hline Bio mass & 14,944 & 16,681 & 14,159 & 15,252 & 16,325 & 13,843 \\
\hline Other & 414 & 269 & 213 & 358 & 425 & 366 \\
\hline Total & $\mathbf{1 9 1 , 0 2 5}$ & $\mathbf{1 8 7 , 1 5 8}$ & $\mathbf{2 0 4 , 1 8 2}$ & $\mathbf{2 2 7 , 9 7 3}$ & $\mathbf{2 6 1 , 7 9 7}$ & $\mathbf{2 9 4 , 2 8}$ \\
$\mathbf{8}$
\end{tabular}

\section{III.SOLAR CITIES IN INDIA:}

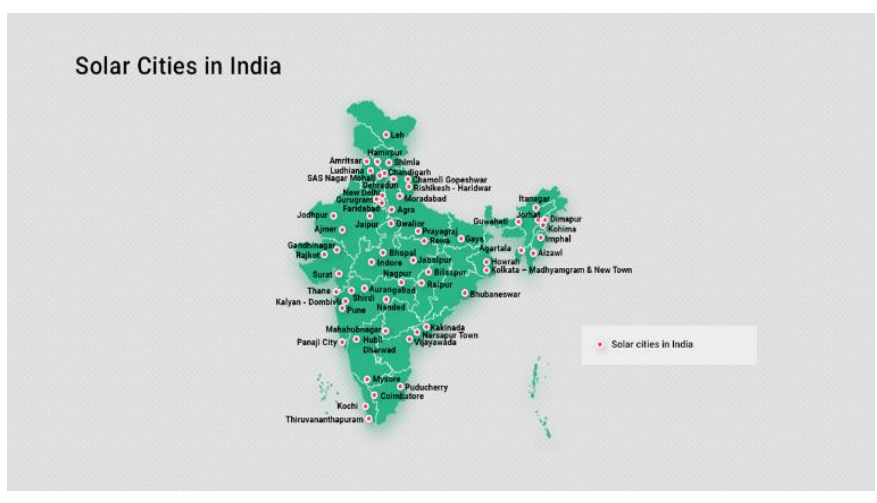

\section{IV.TENDERS OF SOLAR PANELS:}

- In May 2020, about 649 MW of renewable tenders are issued out of which $623 \mathrm{MW}$ of utility scale solar tenders, $23.5 \mathrm{MW}$ of floating solar tenders and 1.57 MW of rooftop solar tenders.

- Supply tender of $400 \mathrm{MW}$ capacity auction is completed for SECI's RTC.

- Due to Covid Lockdown, deadline of bid submission about $22 \mathrm{GW}$ tenders is extended to June and July.

\section{V.MONTHLY IMPORT- EXPORT STATISTICS}

Monthly imports and exports for solar modules in Q1 2020 (Jan-Mar) have fallen substantially by about $70 \%$ compared to previous quarter.

Monthly import and export data of solar modules are as follows:

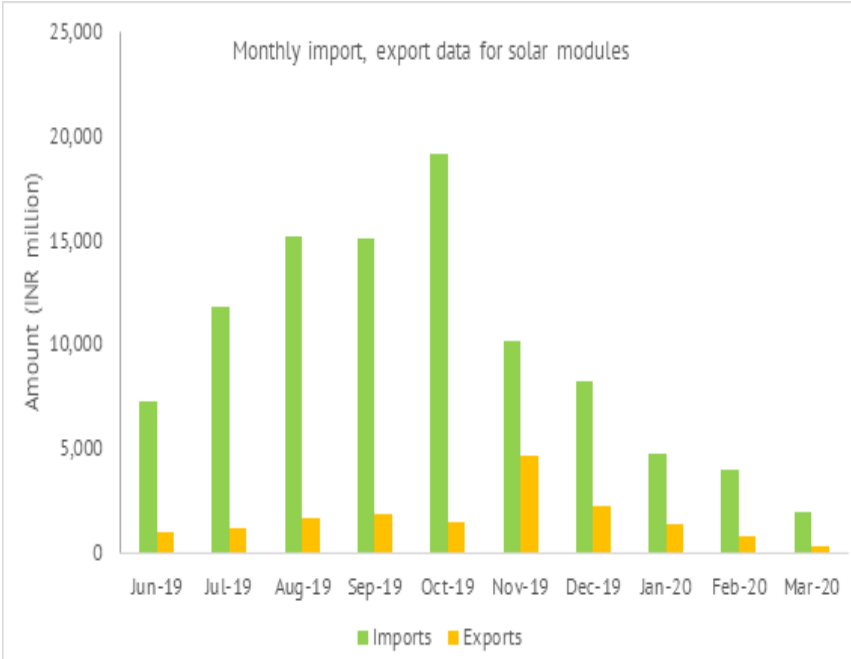

Source: Ministry of Commerce, JMK Research 


\section{GLOBAL PRICE TRENDS:}

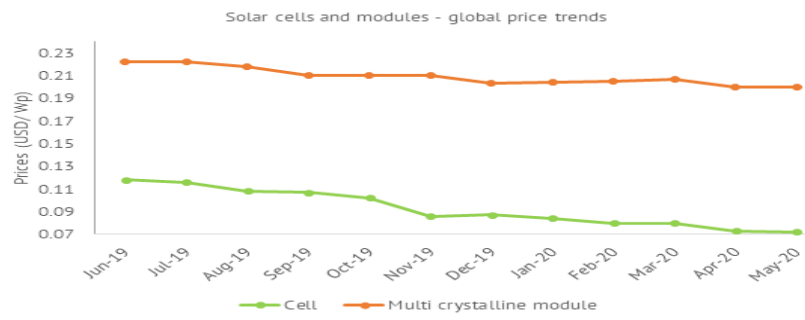

Source: Energy Trend, JMK Research

As we see in the graph prices of cell gradually decreases up to May 2020 and of multicrystalline module approximately remains same. (This price rate is globally.)

\section{INDIA'S LARGEST RENEWABLE ENERGY COMPANIES:}

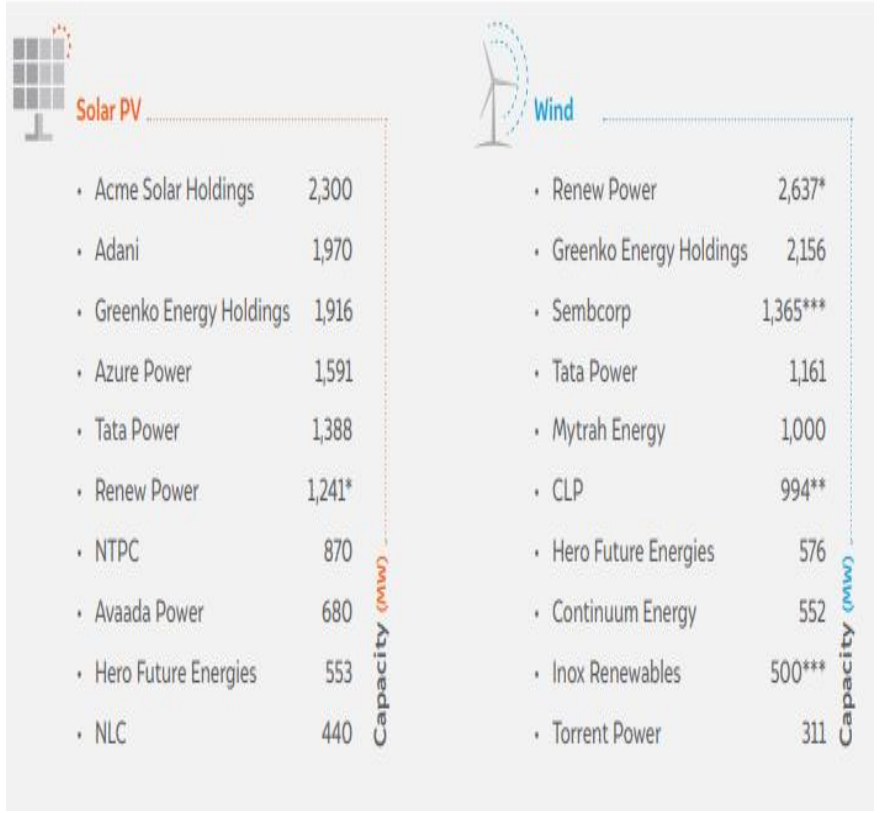

\section{REVISED FIVE-YEAR OUTLOOK FOR RENEWABLE CAPACITY IN GW:}

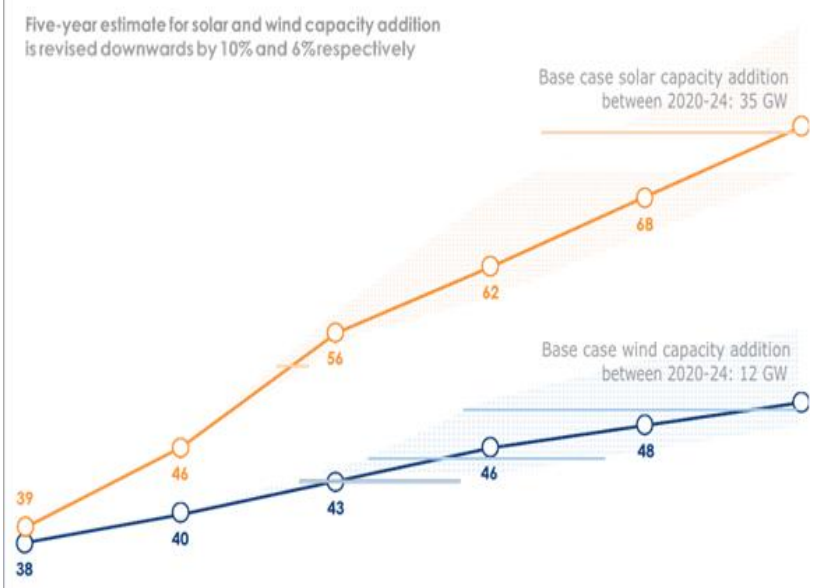

As we are seeing in the graph orange line shows the capacity of solar which is $35 \mathrm{GW}$ in between 2020-2024 while blue line shows the wind capacity which is $12 \mathrm{GW}$ in between 2020-2024.

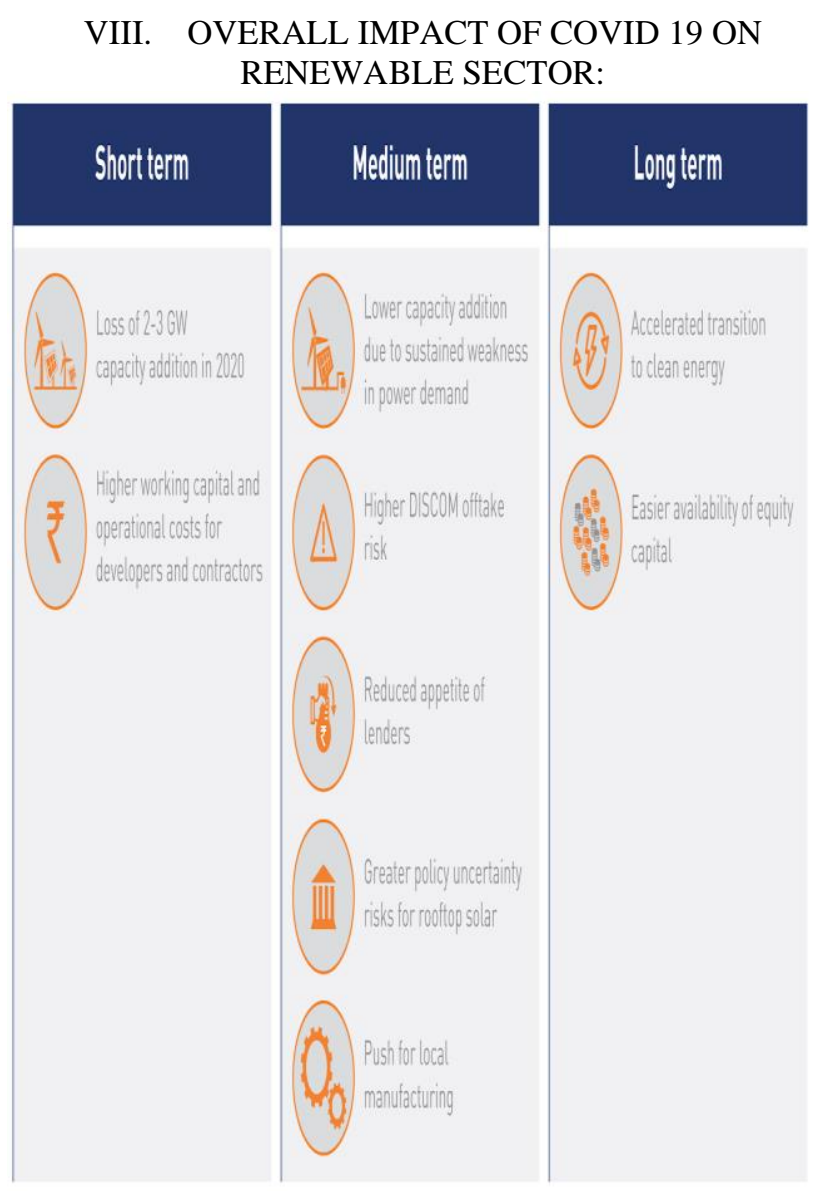

\section{Negative impact on renewable energy sector:}

With number of infections in India still rising rapidly, so there is considerable uncertainty over economic outlook. The energy sector has been hit by multiple increasing demand and supply shocks. Short-term impact on the renewable power sector has been relatively harmful following a series of necessary relief measures announced by the government. But outlook over the next few years appears gloomier due to weakening power demand growth, deteriorating financial condition of DISCOMs and further constraints in debt financing. We have accordingly revised our base case solar and wind power capacity addition estimate over 2020-2024 to 35 and $12 \mathrm{GW}$, down from our previous estimate of $43 \mathrm{GW}$ and $15 \mathrm{GW}$ respectively.

\section{Positive impact of renewable energy sector:}

On a positive note, there is huge optimism about future prospects of renewable energy. The crisis has refocused attention of governments and policy makers worldwide to fight climate change and localise energy supply. So these are the advantages which gives the priority to the renewable energy sources. 


\section{CONCLUSION}

As we are facing the concerns about climate change have made renewable energy sources an important component of the world energy consumption. Renewable energy technologies could reduce $\mathrm{CO}_{2}$ emissions by replacing fossil fuels which are now limited in nature in the power generation industry and the transportation sector. Because of some negative externalities in conventional energy production, i.e. cost and pollution, it is necessary to develop and promote renewable energy sources, technologies and demand for renewable energy. Power generation using renewable energy sources must be increased in order to decrease the unit cost of generation. Energy consumption depends on some important factors including economic progress, population, energy prices, weather, and technology.

\section{FUTURE SCOPE:}

The immense opportunities in power generation, transmission, distribution and equipment will be available over the next four to five years, by the Indian power sector which has an investment of Rs. 15 trillion. While on the other hand plenty of capital chasing the opportunities in the renewable sector, there are several risks that need to be kept in view, including counterparty risks both in terms of developers and producers. India is among the top-five clean-energy producers globally and is well on course to achieve its original target. In fact, it is now set the target of $225 \mathrm{GW}$ from renewables by 2022 and a target of $40 \%$ clean energy by 2030 . India looks set to remain an attractive destination for investors with clean energy, with the government setting ambitious targets and pursuing several reforms to boost investor confidence.

According to study, India's share of total global primary energy demand is set to approximately double to around $11 \%$ by 2040 . India will need to double its electricity output by 2030 to meet this large increase in demand, while also honouring its commitment to reduce its carbon footprint by $35 \%$ from 2005 levels. This would require roughly half of the additional output to come from renewables, which translates to adding $25 \mathrm{GW}$ of renewable capacity annually until 2030. An expansion of this magnitude will require funding of around $\$ 76$ billion upto2022, growing to $\$ 250$ billion which will during 2023-30, as per India's Economic Survey 2018-19. Therefore, on per year basis, investment opportunities of over $\$ 30$ billion are expected to emerge in the next decade and beyond, around three times current levels - clearly indicating a huge investment potential.

\section{REFFERENCES}

[1] https://en.m.wikipedia.org/wiki/Renewable_energy_in_India

[2] https://www.investindia.gov.in/sector/renewable-energy

[3] JMK Research and analysis report

[4] energyworld.com

[5] https://www.cnbc.com 